\title{
CHILD IN THE NATAL NARRATIVES OF MODERN UKRAINIAN MOTHERS: FOLKLORIC SYMBOLS AND FREQUENT MOTIFS
}

\author{
Oksana Labashchuk \\ PhD, Professor, Department of Theory and Methods of the Ukrainian \\ and World Literature \\ Ternopil Volodymyr Hnatiuk National Pedagogical University, Ukraine \\ lov081168@elr.tnpu.edu.ua
}

\section{Halyna Derkach}

PhD, Assistant Professor, Department of Foreign Languages

Ternopil Volodymyr Hnatiuk National Pedagogical University, Ukraine halder@tnpu.edu.ua

\section{Tetiana Reshetukha}

PhD, Assistant Professor, Department of Journalism

Ternopil Volodymyr Hnatiuk National Pedagogical University, Ukraine reshtetyana@tnpu.edu.ua

\begin{abstract}
The article focuses on the manner natal narratives accumulate and transmit prevailing traditional ideas about motherhood and the baby in modern society. It lists and exemplifies the major motifs that are typical of oral tradition of the Ukrainians, Slavs, and other peoples. This research is based on stories of more than 500 women about personal experience of pregnancy and childbirth, which were recorded using the narrative interview method. The thick description method (Clifford Geertz 1973) has been applied for material interpretation. The authors analyse animal-child symbolism in the narration of pregnancy, the accents on weather and time while telling about the moment of birth, and the manifestation of each child's uniqueness in the mother's interpretation.
\end{abstract}

Keywords: childbirth, maternal daily life, narrative interview, natal narrative, oral tradition, pregnancy, thick description

\section{INTRODUCTION}

The narratives of pregnancy and childbirth reflect the woman's daily life in the context of a remarkable and extraordinary event in her life. In today's Ukrainian society, everything that accompanies the expectation and birth of 
a child is extremely relevant and is always emotionally coloured. The object of the following research is women's oral stories about their pregnancy and delivery of a baby, recorded in the form of a narrative interview. The subject of our research is the content of the stories about pregnancy and childbirth. The unit of the analysis is the text of a narrative interview, i.e., the natal narrative.

The topics of pregnancy, birth, and baby care have attracted the attention of folklorists, ethnographers, and anthropologists for a long time. As the article focuses on Ukrainian data, we should first mention here the numerous publications on the traditional maternity rituals of the Ukrainians (Boriak 2001; Chubinskii 1877; Gavriliuk 1981; Gvozdevich 1997; Iashchurzhinskii 1893; Kaindl 2000; Kravchenko 1928; Malinka 1898; Mushinka 1961; Onishchuk 1912; Shekerik-Donikiv 1918). For our study, the publication of records by Marko Grushevskii is considered to be the most significant, since it contains not only ethnographic materials, but also a detailed recording of "conversations of women in the countryside", i.e., stories about pregnancy and childbirth, coming from the lips of the people (Grushevskii 1906, 1907).

The anthropological turn from the analysis of the rural maternity rite in archaic cultures towards modern urban societies is of particular importance for our study. Anthropologists scrutinize the contemporary women's experience of giving birth in maternity hospitals, as well as the social institution of motherhood in general (Belousova 1998; Budrowska 2000; Davis-Floyd 1992; Krugliakova 2001; Rich 1976; Shchepanskaia 1999; Thurer 1994). One of the research areas in the modern anthropology of birth is the study of narratives about delivering a baby. It has been elaborated in different countries: the USA (Bird 1994; Davis-Floyd 1992; Miller 2005; Rich 1976; Thurer 1994), Poland (Budrowska 2000; Florek 2007; Zielińska 2007), Russia (Belousova 1998, 2003; Razumova 2000), Finland (Marander-Eklund 2000, 2020), etc. This topic is also being discussed at academic meetings, among which the conference "Retelling Familiar Tales of Pregnancy and Birth in European Cultures", held at Oxford University in July 2012, is the most significant.

Nowadays, scholars pay attention to the potential of modern folklore to express hidden symbolic values (Bogdanov 2001; Cherednikova 2002; OrszulakDudkowska 2008; Orshuliak-Dudkovska 2010). Mothers' stories about their personal experience of childbirth contain concepts, beliefs, and stereotypes which reflect our contemporaries' symbolic picture of the world. In this article, the most important semantic elements manifested in birthlore narratives are touched upon. 


\section{MATERIALS AND METHODS}

The methodological approach used for the analysis of the semantics of the natal narrative is partly developed on the basis of the Interpretation of Cultures by American anthropologist Clifford Geertz (1973). Geertz considers Max Weber's statement that a person can be interpreted as an animal "suspended in the webs of significance he himself has spun" (Geertz 1973: 5) as the key to understanding such phenomena. Geertz explains his point of view in the following way:

I take culture to be those webs, and the analysis of it to be therefore not an experimental science in search of law but an interpretive one in search of meaning. It is explication I am after, construing social expressions on their surface enigmatical. (ibid.)

The specificity of our approach to the analysis of the semantics of the natal narrative is based on the identification of meanings in the oral text. Traditional ethnography or anthropology would seek to identify the meaning on the basis of the analysis of the maternal rite or certain forms of social organization, but we are interested in semantic and symbolic layers, which can be found in the text of a woman's story about the experience of pregnancy and childbirth.

Humans inherit the existing cultural symbolic patterns, adding to them a speck of their own designs, based on their personal experience and background. Human behaviour is formed under the influence of two forces: on the one hand phenomena and processes caused by the innate mechanisms, and on the other those (phenomena and processes) controlled by the mechanisms of culture. People can neither perceive nor interpret their individual bodily experiences without alluding to the semiotic basis provided by the culture:

Between what our body tells us and what we have to know in order to function, there is a vacuum we must fill ourselves, and we fill it with information (or misinformation) provided by our culture. The boundary between what is innately controlled and what is culturally controlled in human behavior is an ill-defined and wavering one. (Geertz 1973: 49-50)

People need to semiotize the phenomena occurring to them, thus the experience of pregnancy and childbirth, which in themselves are physiological processes, can be understood and mastered by women through certain cultural mechanisms. Geertz regarded culture as a peculiar context on the grounds of which the phenomena of social life and the behaviour of individuals can be studied. This method is known as "thick description" (Geertz 1973: 10). In our work with the material, we also rely on the contextual approach suggested by Elizabeth Calvert Fine (1984) and Oleksandra Britsina (2006). 
A number of scholars emphasize the importance of the narrative interview method in folklore studies; this method has been the most appropriate for our investigation. Modern folklorists actively use the strategy of autobiographical interview in their research (Orshuliak-Dudkovska 2010; Simonides 1973). For this reason Jeff Todd Titon's suggestion “to define and develop an approach to the life story as a self-contained fiction, and thus to distinguish it sharply from its historical kin: biography, oral history, and the personal history (or "life history" as it is called in anthropology)" is worth mentioning (Titon 1980: 276). Robert Atkinson emphasizes the role of stereotypical scenarios, universal elements, and personal mythology in telling people's life stories (Atkinson 1995), and so does Tatiana Dianova using Russian data (Dianova 2009). Personal narratives are an important source for folklorists in their study of "the social construction of the self through time and the transformation of experience through materials readily at hand" (Kirshenblatt-Gimblett 1989: 142). Elliott Oring writes about the uniqueness of individual life stories as one of the ethnological genres (Oring 1987).

For the aims of the research presented in this article, the collector's conversation with informants was recorded on digital media and then transcribed in accordance with current requirements to preserve lexical, grammatical, and syntactic features of a narrator's speech.

The method of conducting a narrative interview involves the following steps: posing an open question; careful listening to a narrative; non-interference in conversation (except phrases showing the interviewer's active interest). At the end of an interview it was allowed to put first open and then closed questions. For us the method of dividing the recorded stories into separate blocks and segments, which facilitates further research interpretation, has been very useful (Grinchenko 2007).

In total, we interviewed about 500 women who had experienced pregnancy and childbirth. Some narrators were re-recorded. Interviews were conducted in the years 2006-2016. Our respondents are women who mainly live in the western regions of Ukraine. For ethical reasons, we encrypted their surnames, first names, and patronymics in the attached list of informants. ${ }^{1}$ This allows us to keep privacy and confidentiality of the narrators' personal data.

The purpose of this paper is to evaluate the possibilities of contemporary personal narrative usage for the interpretation of today's women's experience associated with childbirth, and to ascertain the semantics of a yet unborn child and a newborn in natal narratives (mother's stories), and its determining by folklore and mythological traditions.

The most important motifs in the natal narratives discussed below are: a child-fish; a child-mouse; unique abilities and extraordinary mind of a child 
in the mother's womb; special weather outside at the time of delivery; a child choosing the best time to come into this world; a unique child; a baby-the-giant, an ugly child.

\section{THE BABY BEFORE BIRTH}

\section{Animal symbolism of a yet unborn child}

In the natal narrative, a child as the object of a woman's desires and expectations is depicted in a positive way, even idealized. The materials at our disposal show that a woman never blames her child for all the difficulties she had to endure; on the contrary, she always perceives her newborn as a source of joy, her greatest happiness and fulfilment of her dreams. A woman's awareness of her own mission of childbearing as a process of creation opens up her way in search for the highest spiritual value - the very value of an infant to his or her mother, the value our interlocutors have told us about in their stories.

Children in the natal narration manifest themselves firstly in the form of a being that appears in a mother's womb and begins to show certain signs of existence, and then - as a newborn infant. But, before that, they express their presence in a symbolic way, primarily through dreams. For example, seeing a live fish or catching a fish in a dream foretells pregnancy. The universality of this idea, as well as its prevalence, ${ }^{2}$ is very impressive.

That's what my mother told me, and her grandmother, and greatgrandmother ... She said: "This dream was pursuing me ... Constantly the same dream ... The fish is swimming, and the water is clear, and then I ... I am coming up to the water. And as I'm walking, I see fish swimming around. The same dream again and again". ${ }^{3}$

When women talk about the first movements or flutters of a baby in the womb, the motif of fish again sounds in their stories.

The feeling is ... like a fish ... with its tail - splash! ${ }^{4}$

And I had a feeling, you know, like you take a live fish, you know, into your hands, and it moves its tail and turns around, like a splash ... Such feelings... well ... maybe a baby in the water... like a fish... is splashing. ${ }^{5}$

The first movements of the baby are similar to those ... like a little fish is floating inside and tickling. ${ }^{6}$

As scholars argue, fish in dreams is a very typical symbol of an expected baby for all the Slavs (Gura 2009: 505). 
The strong child-fish association can also be found in a wider historical and cultural context, and below are random examples from various traditions. Bronisław Malinowski, describing the system of beliefs about pregnancy on the Trobriand Islands, writes about several taboos pregnant women should observe:

She is also allowed to eat meat and fish, but she must abstain from certain kinds of the latter. The fish which is forbidden to eat are such species as live in the submarine holes of the coral. The natives say that just as it is difficult to haul these fish out of their hiding places, the baby would not easily be brought forth. (Malinowski 1929: 227)

It is also prohibited to eat "fish with sharp, pointed and poisonous fins", otherwise "the child would be ill-tempered and continuously wailing" (ibid.). The Slavs do not advise pregnant women to eat fish for various reasons: the baby would sleep with open eyes, would be dumb, etc. Here Irina Sedakova's statement is worth mentioning: "Symbolic and ontological features of various animals in the context of childbirth are usually transferred to the baby" (Sedakova 2018: 149).

Carl Kerényi, a researcher of ancient mythologies, who worked with Carl Gustav Jung, writes about an early Christian theological discussion at the Court of Sassanides, which tells us about a mother called Hera-Pege-Myria, who was pregnant with a child-god, and carried it in her womb like in the sea. "She has but one fish, it is added - the same that is also called her ship" (Jung \& Kerényi 1971 [1949]: 46).

There is a well-known fairy tale about a queen falling pregnant after eating a fish or a snake. Boris Putilov gives an example of maternal magic in the story "The Serpent Bridegroom": "In order to cure the infertility, it is necessary to weave a special beaded net, throw it into the sea and catch a fish with six wings; take one wing, cook it and give it to the childless Queen, and throw the fish back into the sea" (Putilov 1999: 58).

Some peoples of the world (in Brazil, Mongolia, Venezuela, etc.) have a mythical idea about the fish transformation into the first people or women (Berezkin \& Duvakin n.d.).

In the narratives of Ukrainian women, it is not only a fish that predicts pregnancy, but other living creatures, too: "As for me, my pregnancy was preceded by a dream: I was at home and was warming four or five small storks under a large table lamp." We can assume the connection of this dream motif with the belief that the stork brings babies, widely known among the Slavs (Gura 1997: 659-661) and, in particular, the most intensely recorded in western Polesie and in the lands of the historic Galicia (Halychyna) and the Carpathian region (Vinogradova 1995: 174-175) where our study was conducted. 
Belief, unlike a biographical memoir, outlines a wider range of living creatures that can foreshadow pregnancy: "If you see a calf in your dreams, it means that you might be pregnant"; "when a chicken hatched from an egg in your hands, it means pregnancy and you will soon have a baby."

According to our materials, not only dreams, but also other situations and contexts give signs about a baby to come to the world. We have put down a story from a woman who symbolically links the beginning of her pregnancy to a crane, repeatedly arriving in her yard. ${ }^{10}$ The symbolic proximity of the images of a crane and a stork is observed in the Slavic languages and folk customs (Gura 1997: 646).

In the analysed narratives, besides fish and other animals, the child's first movements are compared with the movements of a mouse: "Well, it's like a mouse waved with its tail"; "11 "You know... it's like a mouse is rustling... slipping"; 12 "It feels like you have a mouse in your belly". ${ }^{13}$

According to the ideas of some inhabitants of the Trobriand Islands, at the beginning of pregnancy a spirit-child or pre-incarnated baby penetrates into a woman's body: "It was simply like the foetus in the womb ... looks like a mouse" (Malinowski 1929: 176-177).

Mice are connected symbolically not only with children, but also with their mothers. In western Ukraine, there is a belief that the belongings of a lady who refuses to help a pregnant woman will be destroyed by mice. Other examples of the mother-mouse association may be found in Belarus: if a peasant going to the field to sow or carrying grain harvest home meets a pregnant woman on his way, the bread will be eaten by mice (Gura 1997: 406). A decoction made by boiling a mouse in the water or milk was given to nursing mothers so they would produce more breast milk (Gura 1997: 403).

As mentioned above, women often compare the first moves of their unborn babies with the movements of various living beings: chicken, worm, duckling, butterflies, etc.

One day I felt that there was something in my tummy that seemed to be a chicken and it moved with its tail, such was the feeling I had... and I realized that it was my baby moving. ${ }^{14}$

The first kick ... the move was as if a worm was slipping. ${ }^{15}$

The first time it moved was like a duckling pecking inside my tummy. ${ }^{16}$

Then, somewhere at the beginning of the fifth month, I began to feel that the child was moving inside ... at first it was like butterflies in the womb. ${ }^{17}$

In the imagination of a mother her baby is associated with a white dove, which she perceives as a heavenly angel. 
And three weeks before I gave birth, my husband went away to Canada for work, and I had to live with my parents. And once we had a fight... well, it was some ordinary domestic conflict, and I ran out into the garden, crying. I felt terrible. And I thought, if it were not for the child, I would live in Ternopil and nobody would humiliate me. [crying] ... And suddenly and unexpectedly in front of my eyes, God knows where it came from, a beautiful white-white dove appeared. It flew and sat on the fence and looked at me with such clever black eyes. And I felt God's grace. I thought it was from Heaven that my yet unborn daughter's guardian angel flew to make me stop thinking such foolish sinful thoughts and to make it clear that my child, like that white snow dove, emm ... due to its purity, innocence, nobility and kindness (well, it's just the way our Nastunia is), will be a great joy and support for me in the future. Thus, having calmed down, I went home and made it up with my parents. ${ }^{18}$

In his Notes about the Southern Rus, Panteleimon Kulish presents the following story illustrating the animal-child symbolism in folk culture:

Once a woman was out in the fields, and a wise woman hid in the corner [of the room] to observe. Suddenly a child crept from a cradle: oh, look! It was not a child, but an old man. Short, with a very long beard! [He] took out the pots from the stove with an oven fork, and began to stodge the meal, groaning. Having done his work, he turned into a child again. When the wise woman started beating him with a broom, he revealed his secret: "I, Granny, have repeatedly transformed, not once and not twice: first I was a fish, then I became a bird, an ant, an animal, and now I have tried to be a human." (Kulish 1856: 34-35)

The animal hypostases of an unborn child are interpreted by Mircea Eliade, who relates similar views to the myths about Mother Earth, which is the mother of all living creatures on Earth. A woman becomes pregnant when souls-children, living inside the Earth, penetrate into her. Thus, according to European beliefs of the nineteenth century, children are brought by aquatic animals (Eliade 1959). Balkan peoples use zoological language code, such as 'sparrow', 'puppy', 'kitty', etc. for the denotation of a not yet christened child, claims Irina Sedakova (Sedakova 2007: 43-44).

Therefore, we can see that the connection of an unborn child with animal hypostases, especially a fish and a mouse, is deeply rooted in the culture of different peoples worldwide and is preserved in the Ukrainian modern oral tradition. In general, the correlation child-animal is a characteristic feature for both traditional and contemporary cultures (Panchenko 2004). 


\section{Child's behaviour in the mother's womb}

One more motif we should pay attention to is how a child shows its presence in the mother's womb. In addition to the first moves, which women compare with the movements of various animals, there are other manifestations of an unborn child that are reflected in the natal narratives.

First of all, women often express surprise at the fact that a "creature" is moving in their belly:

Because a kind of life has appeared in my belly ... and it knocks, rumbles, kicks, moves its hands, feels everything. And I think, when it is born, what will happen next. ${ }^{19}$

It is impossible to describe what it looks like. It's as in the movie "Alien", when something is formed in your tummy and moves with its feet and hands. ${ }^{20}$

For a present-day mother it is natural to compare a boy in the womb with a football player: "It was such an interesting feeling, my baby was moving so much as if a footballer lived in my tummy." ${ }^{\prime 1}$

Most women, when describing their unborn children's first movements, note a special pleasure, emphasizing on the uniqueness of such feelings and the impossibility to experience them in any other way.

It was very interesting when the child started to move. It was such a feeling that someone lives inside of you, that you give somebody life.... it seems it wants to say something to you. ... It's so nice, so it's some kind of an unusual feeling. It cannot be described by words, it only needs to be experienced, and it only needs to be tried. ${ }^{22}$

And I always, when I was on the seventh or the sixth month, when I had already such a tummy, I always loved to put my hands on my tummy, when ... there was nobody near, I put my hands on my tummy, and I talked to my son. ${ }^{23}$

However, in contrast to these idyllic stories, some women point out that it was difficult to endure the very active and sharp movements of the child:

I remember the feeling, but how to describe it? Sasha hit my liver and scratched with his nails. I was told that there could not be such things, but that was really the case. He was born with such a manicure. ... He scratched like a real rat. It hurt so much that I got goose bumps. And they fought like horses, both. I thought that my tummy would break. ${ }^{24}$ 
Such evidence can be taken as a text implementation of the epic motif "Even being in the womb, my child was exceptional", as well as the motif associated with heroic deeds: "During pregnancy I had to endure incredible difficulties".

A child, according to some women's stories, not only "talks" with the help of the language of movements with its parents, but even understands and listens to them:

And our daughter loved when her dad was stroking her. When he put his hand on my tummy, she tried to place herself under his hand. They say that a child feels its family. I think that's true. Always, when Andriy or I touched my tummy, she would always place herself in our hands. It was very nice to understand that she knew her mum and dad. ${ }^{25}$

When my tummy had gotten bigger, and when the child began to move, my husband and I started to read her fairy tales. We had the impression that she was listening... even when we were reading fairy tales, we talked to her and said: 'If you hear us, knock on mum's tummy' - and she knocked and even pressed with her leg or hand, or a finger, which could be seen. ${ }^{26}$

Once it was like a hurricane in my tummy, but when my husband touched it, there was silence at once, as if they knew that with their dad they should be calm... ${ }^{27}$

The next motif, realized in some mothers' stories about their unborn child, is as follows: "Unlike other children, my baby was unique even in my womb; besides, it has already had special abilities and an extraordinary mind":

We even laughed: "Viki should be very smart, because she has already completed a master's degree programme with me". ${ }^{28}$

I became smarter. I came up with such brilliant ideas that I was surprised myself. When I was taking my exams, I asked my baby to help me. I asked him to control my intuition and told him that he was very intelligent. And I passed my exams well. ${ }^{29}$

The baby develops household abilities: "I remember that every week I had to sweep the yard, so I can say that Vasul'ko [her son], even when being in my tummy, helped me to do my housework."30

Your own child, as the narratives manifest, is not only the most intelligent and hardworking, but his or her behaviour is different.

For example, my husband puts my hand on my tummy, and our baby kicks right in the place where his hand was. ... even the leg was visible [smiles] .... he was very fast, as he is now ... here and there ... And when we were 
doing ultrasound, they all said that they had not seen that a child was moving so much inside [laughs]. ${ }^{31}$

The key formula that doctors "have not seen such a baby or quality yet" is often present in the stories of an unusual birth and uncommon behaviour of the infant.

The next motif reveals the idea that a child behaves in the womb regardless of his or her mother's will. All changes in mother's activities, as well as her preferences and tastes, are determined by the wishes of her child.

Well, I had a large foetus ... It was my own fault... Mine and Olezhyk's... fifty-fifty! Because he was a great eater! [laughs] And I was getting up at night to eat meat. ${ }^{32}$

I became very plain, even ugly, face ... [laughs] Yes! ... the face was covered with pigment spots. [to her daughter]: You have probably stolen away my beauty! ... And I always wanted to eat. That's why we have such a gourmet now! $!^{33}$

It was quite an important moment ... When my husband was watching football matches on television I sat with him and watched ... Probably because I was bearing a boy. My husband would say to me in amazement: "But you hate football!" At that time, football became quite an interesting game for $m e{ }^{34}$

The child even determines the time to be born:

Dimochka took his time to be born. I gave birth to him on the forty-first week, not on the fortieth. ${ }^{35}$

Tamila wanted to see the world as soon as possible, she knocked to get out, during the last months it was impossible to withstand pregnancy, she almost wanted to escape... ${ }^{36}$

The child's emotions and feelings can directly master the process of childbirth: "Though I was having a contraction, my uterus did not open, perhaps the baby was afraid..." 37

Here is another motif inherent in the natal narrative: mother's behaviour influences the formation of her future child's character traits. The features a child manifests while in the womb will mould their character:

I was into books when I was pregnant, so you [to her first daughter] are such a bookworm - studied at school very well, graduated from school with honours, study all the time. Nastya, [another daughter]...when I was pregnant with Nastya, I was in motion, so Nastya is such a mobile girl. She likes physical education, sports. She is the first to help about the kitchen, 
likes to cut groceries. Therefore, during pregnancy it is important to take into account your own behaviour, activities, words or even the kind of music you listen to. What you do greatly influences the foetus. It's true. ${ }^{38}$

When I was pregnant with Olya I was dancing almost all the time, till the delivery... at my brother's wedding I was dancing and waltzing around ... and Olya - she loves parties, dancing and singing. But with this oneVitalik - I was nervous, was studying ... thus he is so annoying. ${ }^{39}$

In the traditions of all the Slavs, the period of pregnancy was full of prescriptions, prohibitions, and observations because it was believed that the behaviour of the expecting mother affects the appearance, character, health, and behaviour of the future child both directly and, to a greater extent, also symbolically (Tolstaia 1995: 160-164). In a broader perspective, the abovementioned stories allow us to draw a parallel between the natal narrative and the etiological legend, which, in fact, explains the properties of certain phenomena, objects, and creatures by the peculiarities of their origin (Kachmar 2010). Similarity is seen at the semantic level: even being in the mother's womb, a human possesses certain traits which are revealed after birth and develop into their characteristic features. Actually, such features become apparent because they were formed in the womb.

\section{DELIVERY: WEATHER AND TIME SYMBOLISM IN NARRATING}

The birth of an extraordinary infant - a future god, a hero, the founder of a ruling dynasty - is a well-known and frequent motif in a great number of mythological texts (Campbell 2004 [1949]: 295-308). Unusual or 'magic' infants, according to Ewa Nowina-Sroczyńska, are extraordinary children: they are born in uncommon circumstances and behave differently. In the texts representing various mythological traditions and traditional culture, "the signs of the newborn's superiority were supernatural - as they thought - phenomena that marked their birth" (Nowina-Sroczyńska 1997: 52). Such births are accompanied by storms, earthquakes, and volcanic eruptions.

In the natal narratives of the modern Ukrainian women, the weather outside at the time when a child was born is a common motif.

I remember: I'm lying and looking through the window. Such a strong, heavy rain and wind, the weather was not so good, but I was so happy and it was so easy... easy and so good, it was good..$^{40}$

I was in the maternity ward, and, despite August, it was terribly cold. There was a thunderstorm outside the window. ${ }^{41}$ 
When he was born, it was dull weather ... I wondered: why so? The whole week before, until the ninth of September ... it was warm and sunny, but on that day the weather changed at once: the rain started, the sky was overcast, the wind was blowing. ${ }^{42}$

Other women remember that at the moment of their child's birth, the weather was very good, consonant with their great mood:

Having given birth, I looked through the window. It was a very bright sunny day. And my first feeling was something weird and very, very pleasant. Apparently, I was the happiest person in the world then. ${ }^{43}$

I was lying on the table in the maternity home and looking through the window: it had stopped raining, and I remember golden leaves with droplets of rain sparkle in the sun; the weather was wonderful outside. ${ }^{44}$

Well, I was lying, and it was an extremely beautiful dawn ... it was June, such a beautifully pleasant June morning ... the sun was so nice... such a pleasant morning. ${ }^{45}$

Actually, looking up at the sky during the most significant moments of life is what Mircea Eliade writes about: "The sky remains ever present in the religious life by virtue of its symbolism" (Eliade 1959: 128). According to one woman's story, the weather on her daughter's day of birth influenced all her next birthdays: "My daughter Larisa's birthday always falls on rainy days... Always rainy, you know ... maybe because she was born on a rainy day. ${ }^{346}$

Another narrator connects the girl's cheerful mood with the weather and the time of the day of her birth:

It was a wonderful morning. The delivery was easy ... when I was giving birth, and the rising sun was shining into my eyes. And then I thought that my child would be as joyful and bright as that day was ... And so it is! $!^{47}$

In various Slavic traditions, different weather conditions being observed during delivery acquire a special magical and prognostic status (Kabakova \& Sedakova 2004: 260). We assume that in the modern narratives, these weather observations may take on a similar meaning.

An important motif for the natal narrative is that the time when a baby comes into this world is the best for it. Even today there are beliefs that each child chooses the time of his or her birth: "Well, I do not know ... a child... will be born at the appropriate time." ${ }^{.8}$

Ewa Nowina-Sroczyńska writes that 'holy children' tend to appear at a particular sacred time, especially at midnight or at dawn, or on the day of a great religious feast (Nowina-Sroczyńska 1997). At the same time, it could 
be considered as a cultural universalia that "individual calendars of a woman and her child fit into other calendars - natural and festive - and the points of coincidence or sameness are recorded and marked ... Time of the day, day of the week, season, year, church and family holidays - all these points are extremely important in a prospective and retrospective interpretation of life circumstances" (Sedakova 2011: 183; see also Grushevskii 2006: 48; Shcherbak 2008: 51-52).

In our research materials, some examples of the role of the temporal factors within the framework of the ritual year could be found. A woman whose worldview is oriented to the Ukrainian traditional culture emphasizes that both her children were born on major religious holidays: "My children were both born on big religious holy days. You, Julia, on Pentecost Saturday, and Taras on Easter Monday." 49

In the narratives of these women who are carriers of modern culture, we still find time reference as a significant obstacle:

It's a great time, s-u-u-u-mmer! I want all children to be born in summer, because ... our child was baptized two weeks later and we went outside for a walk with him... for nearly the wh-o-o-ole day. ${ }^{50}$

But I am very happy that my daughter was born in my favourite season, autumn. I really love autumn; I myself was born in November ... for me it is very important. ${ }^{51}$

My Nastya was born at $6 \mathrm{pm}$. The thing that it was not at night ... I was very afraid of giving birth at night. I don't know why. Probably, I was afraid if the doctors could manage ... Maybe I realized that it had already begun. But the very fact of night frightened me. I'm afraid of darkness. ${ }^{52}$

The semiotization of calendar periods in which the child was brought into the world is also characteristic of traditional culture. Thus, Inna Shcherbak writes:

The names of children were associated with the season in which they were born: 'zymak' (from Ukrainian zyma - winter, for a child born in winter), 'osin'chuk' (from Ukrainian osin'- autumn, for a child born in autumn); with a religious fast - 'petrivchenia' (for a child born during St. Peter's fast), the month of the year - 'marchuk' (for a child born in March). (Shcherbak 2008: 57)

Women's extraordinary attention towards the time of their children's birth is a relevant point in such birth stories. One of our interlocutors emphasized the symbolic coincidences of the day of the month and the time when her children were born, whatever question we would ask her regarding children: 
That was the case. Both my children were born on the 15th day of the month. Son at $4 \mathrm{pm}$, and daughter at $4 \mathrm{am} .{ }^{53}$

I had been giving birth for approximately ten minutes. At seven forty-five. Exactly. By the way, [to her child] you were also born at seven forty-five. ${ }^{54}$

For example, my son was born on 3 April, wasn't he? For me, number 3 is a landmark, well, I do not know why ... I was born on the third, but only in September ... so, number 3 inspires me with some kind of confidence, hope, optimism, and this number somehow helps me in my life..$^{55}$

The date and time of a baby's birth in some women's stories undergo symbolization and change into meaningful numbers which have an impact on their child's future fate.

I do not know, it seems to me, because of the fact that I was giving birth on such a great day (it was Easter Friday), on the eve of the most incredible and greatest holiday in the world - Easter, everything was so easy ... And on 13 April, at 14:20, I gave birth to a girl. ... Since my second baby was born on Easter Friday, on the 13th day of the month, I believe that number 13 should bring her only good luck and goodness. ${ }^{56}$

In addition to the daily and calendar birth symbols, it is necessary to mention that in traditional Ukrainian culture the mother was the donor of the fate of her child. The fate is given at the moment of birth, and its good or evil luck depends on the mother (Ivanov 1992 [1991]: 344). The belief that at the moment of birth a baby receives its destiny was widespread among the Hutsuls - an ethnic subgroup of Ukrainians spanning parts of western Ukraine and Romania (Shekerik-Donikiv 1918).

\section{NARRATIVES ABOUT A NEWBORN BABY}

The narratives of Ukrainian women depict the birth of a child as an extraordinary event in a mother's life, and correspondingly the child is unique, not like other children. In part, this motif is realized when a mother tells about her 'not ordinary, unusual' pregnancy, 'not ordinary' childbirth and a child who even in the womb behaves 'in another way'. For each mother, her child has unique abilities; it behaves differently, clearly showing its distinct features. Among contemporary natal narratives, there are memories of a special cry, a special look, a special mind, a special beauty of the baby right after the birth. In this regard, modern narratives about children have something in common with the 
traditional description of fairy-tale's children, which are usually treated as different (Nowina-Sroczyńska 1997).

And you know ... he never cried like any other baby. Children cry, but he simply screamed: 'oh', 'e', 'oh', ' $u$ ', and then 'ma', 'ba'.... Well, he screamed so much that I remember everything. And while he was screaming there, they all stood around him; in short, he was born, and at once gathered the audience around himself. ${ }^{57}$

As she was born, they showed her to me. It seemed to me that I hadn't given birth to a child, but a very nice doll. Sometimes, as you look at someone's baby, you think it is ugly, wrinkled ... And mine, she was such a beauty, the prettiest of all in the whole maternity house. ${ }^{58}$

However, as Ewa Nowina-Srochyńska observes, the most exposed motif for the birth of a 'holy child' is the motif of adult reactions and adult behaviour (Nowina-Sroczyńska 1997: 59). Present-day mothers often say that their newborn babies, unlike other children, looked much older:

On the first day when my husband came in the evening, he took photos of our daughter somewhere eight or nine hours after her birth, and sent the photos to our relatives ... It seemed that it wasn't just a newborn, but a one-week-old baby. ${ }^{59}$

Marichka was plump from the very beginning. She looked like a onemonth-old baby; it wasn't terrible to hold her. ${ }^{60}$

The baby weighed 3,400, and was 51 centimetres tall, but it was very big! A very large head, very broad shoulders, like a three-month-old baby. ${ }^{61}$

The baby was born large: its weight was 4 kilograms, and she was 50 centimetres tall. It was such a big child ... at the age of one week he looked like a baby of a month and a half... It was such a very big, beautiful baby. It seemed as though it was about two months old. ${ }^{62}$

The first meeting of a mother with a premature baby is also described with the motif of special abilities the infant acquires immediately after birth:

There I saw my baby, he was lying under the hood, and then I realized why he was not given to me. There was nobody near him; I came up, he was so pretty, like an angel: his hair was black, his cheeks were small and he clenched his fists and put them under his little head and slept in such a way; he always slept like that, and doctors were surprised that such a small baby knew how to sleep. ${ }^{63}$ 
However, according to our material, the most exposed motif used by mothers when they are telling about their first meeting with the child is the motif of a baby-the-giant.

Vladik ... surely was a giant. In my ward, two women gave birth to girls, they were so thin, so miniature; their mother could take them under the armpit and lie down. And then they brought me my Vladik, he was so... plump cheeks ... and I remember that there were two girls and he was between them, like a knight. ${ }^{64}$

In our opinion, the motif of a baby-the-giant is an example of the direct influence of the heroic epos on the tradition of telling about the birth of a child, which we observe in present-day mothers' stories.

Another frequent storyline shows a baby unattractive at first glance, who then turns out to be handsome, as if a miraculous transformation took place.

Oh, my God, I will tell you honestly, when I saw my first child, I was scared. It was so ugly, blue, and miserable! But when I got her, washed, dressed, swaddled and hugged, when I saw her beautiful hazy eyes, I couldn't believe how pretty she was. ${ }^{65}$

He was so terrible, you cannot imagine. He had such swollen lips... swollen eyes; he looked like my husband when he was drunk. Well, but when I looked at him in the morning, I saw - he was so handsome. ${ }^{66}$

When I looked at my husband, he was standing there in fear, looking at the baby, and then quietly said: "And why is she so ugly? I was even a little hurt. But when our daughter was beautifully dressed, swaddled ... she became like an angel. ${ }^{67}$

A baby was born with such a long head like a squash [laughs]. ${ }^{68}$

Sometimes the motif of an ugly child becomes an impetus for the deployment of a story about maternal fears and emotional experiences.

I remember when Ira was brought for the first time. Our dad had been in Chernobyl, and everyone asked me whether I was afraid to give birth, because the child might be somehow abnormal, with defects. So, Ira was brought ... At that time children were swaddled, not dressed into clothes, as it is now. And my child's face was swaddled very tightly. I looked-all children were as children, and I had a hamster. I was terrified ... I didn't say anything to anyone ... But when the child was brought for the second time I saw that everything was okay, and I calmed down". ${ }^{69}$ 
These ideas can be linked to the traditional Slavic beliefs, which view the infants before christening as not real human beings, but part of the 'other', demonic world (Kabakova 1999: 86). They are regarded as evil spirits, ${ }^{70}$ unclean, ugly, bad (see the list of over 80 pejorative names the Bulgarian call their babies until they are christened in Sedakova 2007: 45-47). These ideas may have some influence on the symbols in the modern natal narratives under discussion.

Another important idea is that of a baby as a gift. Stories about taking a newborn home from the maternity hospital emphasize that a child is a treasure a woman gains after enormous pain and suffering:

My husband came and we went to the room where babies were dressed. It was very nice to see how such a small God's creature was swinging with its little arms and legs ... She was very thin and little. And a midwife gently dressed her into new clothes, bought by her daddy, a hat, an undershirt... My husband bought everything. My daughter's grandmother, my mother, had made a very beautiful blanket slip... ruched, a hat with flowers embroidered all around... she was like an angel. The baby was dressed and wrapped, because she was little and needed the warmth. ... so, she was wrapped and handed to her dad. And she was tied with such a pink ribbon, with a bow ... The happy dad went down the stairs ... descended, and sat in the car. We arrived home ... arrived, and there was nobody at home. Grandmother and grandfather were at work. We arrived home, and at home everything was clean, the flowers ... because everyone was waiting for the baby to arrive. We put the baby into the crib, unwrapped her, and looked at her with admiration. ${ }^{71}$

Some more stories depict an infant as a precious and at the same time a fragile treasure:

We were desperate when Timur was brought to me for the first time, and you cannot believe that it is your child, and you think: "Oh, God, what should I do next?" It is so weak, you are afraid to hold it ... the scene is so moving. ${ }^{72}$

When the nurse left and I needed to dress up Vika, I was so scared; I didn't know how to dress her up. I was afraid lest I should break her arm or leg. And I wondered about how to change her. I asked the nurse, and she said: "Take it, it is your child, change her", and went out. A woman in the ward said: "Tanya, come on, I'll help you" ... She came, and we changed her. ${ }^{73}$

A day later we bathed our baby. After bathing, she slept like a little angel, and I listened to whether she was breathing. ${ }^{74}$ 


\section{CONCLUSION}

The natal narrative depicts a child as an object of a woman's desire and expectation, which is why it is portrayed positively, even idealized. The materials analysed show that a woman never accuses her child of all the difficulties and pains she had to go through; on the contrary, she always perceives her newborn as a source of joy, a gift, her greatest happiness and the fulfilment of her dreams. A child in the natal narrative is shown first of all as a creature that appears in the mother's womb and begins to manifest certain signs of existence, and later as a newborn. Each mother speaks about her child as a unique one, very different from other children. A 'unique' child still being in the womb behaves differently: moves in a special way, shows unusual mind, 'communicates' with parents, etc. The natal narrative realizes the following notion: an unborn child influences its mother: all the changes in her behaviour, preferences, and tastes are determined by the baby.

In the stories about a child in the mother's womb, animal images of a mouse or a fish are often used. The correlation child-animal is well-developed in the texts under analysis and has a symbolical basis deeply rooted in many traditions.

In the modern narratives, the birth of her very child for each mother is an extraordinary event, and her child, unlike other children, is special: a baby is gifted with unique abilities and features that expressly testify to its uniqueness; its behaviour is special even in the womb. The baby is born at a special time, for example, on a religious holiday; it chooses the best season of the year, the best time of the day, rainy or sunny weather. The motif of describing the sky and the weather right after the birth of a child is typical of the natal narrative. A 'unique' baby immediately manifests its exceptional features: loud voice, sensible look, precocious mind, unusual beauty, etc.

The most exposed motif at the birth of a 'unique' child is the motif of adult reactions and adult behaviour. In our opinion, the motif of a baby-the-giant is an example of a direct influence of the heroic epic on the tradition of telling about the birth of one's (own) child, which we trace in today's mothers' stories. One of the cliché expressions that is still used to characterize a newborn boy is "the future head of the collective farm". Such a nomination, although it is an echo of the Soviet era, demonstrates the desire of a woman to distinguish her baby among other newborns, show its strength, physical health, and high social status in the future. Stories about returning home with a child from maternity home emphasize that a child is a precious treasure that a woman gained through pain and suffering.

The main symbols and ways to ascertain values to child's characteristics in the modern narratives under investigation show the parallels with the 
respective elements of the Slavic traditional cultures, the Ukrainian one in the first place, but also beliefs from all over the world. This proves the high potential that the narratives about life events have for studying the symbolic picture of the world of our contemporaries.

\section{NOTES}

1 The data mentioned in the references are presented in the following order: the collector's name and the year of recording; the initials of the narrator; the age of the woman at the time of recording; number of births.

2 A fish has multiple symbolic meanings in the texts of birthlore. In dreams it predicts pregnancy, but for a pregnant woman there are some activities with fish which are considered dangerous for the future baby. Thus the idiom "He is dumb as a fish" is taken literally, and produces restrictions: scaling or gutting and eating fish is considered to be a taboo for pregnant women - the child may be delayed in speech if this prohibition is violated: "You see... Lenka's boy was silent for three years, he did not speak at all, only 'mu-mu', 'liu-liu', 'siu-siu' ... Dimka [her husband] was a fisherman, and on Sundays she scaled and gutted fish... Wherever there is a superstition - follow it!" (Labashchuk: 2016, KAD, 46, two children).

3 Labashchuk: 2008, HOS, 51, three children.

4 Labashchuk: 2009, GP, 39, two children.

5 Labashchuk: 2006, RTV, 35, three children.

6 Rybak: 2008, BHP, 23, one child.

7 Kaftan: 2009, POM, 19, one child.

8 Pitula: 2009, GHI, 62, three children.

9 Vozniuk: 2009, UTS, 34, three children.

${ }^{10}$ Verbovskaia: 2012, XIV, 23, two children.

${ }^{11}$ Labashchuk: 2016, KAD, 46, two children.

${ }^{12}$ Labashchuk: 2009, SAS, 36, two children;

${ }^{13}$ Pitula: 2009, ILG, 39, two children.

${ }^{14}$ Gavronska: 2012, BOV, 42, one child.

${ }^{15}$ Kalinovska: 2012, KMM, 22, one child.

${ }^{16}$ Kharkovets: 2012, KhZhM, 41, two children.

${ }^{17}$ Shandyba: 2012, HLV, 21, one child.

${ }^{18}$ Starko: 2011, SOH, 44, two children. 
${ }^{19}$ Denega: 2011, ROM, 32, two children.

${ }^{20}$ Savchuk: 2011, DMM, 40, three children.

${ }^{21}$ Belaia: 2011, NNT, 23, one child.

${ }^{22}$ Mostova: 2011, TIM, 24, one child.

${ }^{23}$ Vovk: 2011, SUB, 26, one child.

${ }^{24}$ Labashchuk: 2008, PIM, 39, two children.

${ }^{25}$ Loshniv: 2012, SWL, 24, one child.

${ }^{26}$ Soltys: 2011, ROV, 26, one child.

${ }^{27}$ Verbovska: 2012, KIV, 23, two children.

${ }^{28}$ Mostova: 2011, TsIM, 24, one child.

${ }^{29}$ Kalinovska: 2012, KMM, 22, one child.

${ }^{30}$ Babak: 2011, GVI, 28, one child.

${ }^{31}$ Rozvadovska: 2011, ShIV, 21, one child.

${ }^{32}$ Zymnytska: 2011, CAZ, 44, two children.

${ }^{33}$ Starko: 2011, SOG, 44, two children.

${ }^{34}$ Vitiak: 2011, UIV, 23, two children.

${ }^{35}$ Vovk: 2011, NLM, 23, one child.

${ }^{36}$ Mular: 2011, LOB, 41, two children.

${ }^{37}$ Romaniv: 2011, OGP, 46, two children.

${ }^{38}$ Salamandra: 2011, SNB, 39, two children.

${ }^{39}$ Fedirko: 2011, HNM, 46, two children.

${ }^{40}$ Rutka: 2012, ROP, 42, three children.

${ }^{41}$ Starko: 2011, SOG, 44, two children.

${ }^{42}$ Kostetska: 2011, AKV, 23, one child.

${ }^{43}$ Babak: 2011, GVI, 28, one child.

${ }^{44}$ Maidaniuk: 2011, MOA, 37, four children.

${ }^{45}$ Shmilo: 2011, ShHP, 41, two children.

${ }^{46}$ Kolesnik: 2012, VOS, 40, two children.

${ }^{47}$ Starko: 2011, SOG, 44, two children. 
${ }^{48}$ Fedirko: 2011, GNM, 46, two children.

${ }^{49}$ Havryliak: 2012, SOV, 46, two children.

50 Zimnytska: 2011, ZAS, 44, two children.

${ }^{51}$ Krischuk: 2011, SNB, 25, two children.

${ }^{52}$ Loshniv: 2012, ShLW, 24, one child.

${ }^{53}$ Labashchuk: 2012, SSG, 36, two children.

${ }^{54}$ Kohut: 2011, KMI, 46, two children.

${ }^{55}$ Soliak: 2011, ShNL 32, one child.

56 Oliinyk: 2011, OOY, 49, two children.

${ }^{57}$ Labashchuk: 2009, THY, 50, two children.

${ }^{58}$ Novosad: 2012, NMM, 50, three children.

${ }^{59}$ Mostova: 2011, TsIM, 24, one child.

${ }^{60}$ Maksymets: 2011, KMB, 31, two children.

${ }^{61}$ Bachun: 2011, ChTA, 28, two children.

${ }^{62}$ Smakous: 2012, STI, 42, two children.

${ }^{63}$ Holovatiuk: 2012, FIV, 24, one child.

${ }^{64}$ Muliar: 2011, ATO, 27, one child.

${ }^{65}$ Savchuk: 2011, DMM, 40, three children.

${ }^{66}$ Savchuk: 2011, DMM, 40, three children.

${ }^{67}$ Maidaniuk: 2011, MOA, 37, four children.

${ }^{68}$ Dmytryshyn: 2011, DOM, 65, one child.

${ }^{69}$ Kohut: 2011, KMI, 46, two children.

${ }^{70}$ See also an early Western European belief about the souls of children who died unbaptised that would go to hell (Paukštytė-Šaknienè 2020).

${ }^{71}$ Oliinyk: 2011, OSO, 49, two children.

${ }^{72}$ Muliar: 2011, LOB, 41, two children.

${ }^{73}$ Mostova: 2011, TIM, 24, one child.

${ }^{74}$ Shmat: 2011, SHIL, 39, one child. 


\section{REFERENCES}

Atkinson, Robert 1995. The Gift of Stories: Practical and Spiritual Applications of Autobiography, Life Stories, and Personal Mythmaking. Westport, CT \& London: Bergin \& Garvey.

Belousova, Ekaterina 1998. "Nash malysh": sotsializatsiia novorozhdennogo v sovremennoi gorodskoi kul'ture. ["Our Baby": Socialization of a Newborn in Modern Urban Culture.] Zhivaia starina, No. 2, pp. 24-25. Available at https://inslav.ru/sites/ default/files/zhs-1998-2.pdf, last accessed on 7 October 2020.

Belousova, Ekaterina 2003. Rodil'nyi obriad. [Maternity Rite.] In: Aleksandr Belousov \& Inna Veselova \& Sergei Nekliudov (eds.) Sovremennyi gorodskoi fol'klor. Moscow: RGGU, pp. 339-369.

Berezkin, Iurii \& Duvakin, Evgenii n.d. Tematicheskaia klassifikatsiia i raspredelenie fol'klorno-mifologicheskikh motivov po arealam. Analiticheskii katalog. [World Mythology and Folklore: Thematic Classification and Areal Distribution of Motifs. Analytical Catalogue.] Electronic edition. Available at http://www.ruthenia.ru/ folklore/berezkin/e26.html, last accessed on 7 October 2020.

Bird, S. Elizabeth 1994. It's the Talking That's Important: Pregnancy Folklore as Women's Discourse. Women's Studies in Communication, Vol. 17, No. 2, pp. 45-67. https://doi.org/10.1080/07491409.1994.11089782.

Bogdanov, Konstantin 2001. Povsednevnost' i mifologiia: issledovaniia po semiotike fol'klornoi deistvitel'nosti. [Daily Life and Mythology: Studies on the Semiotics of Folklore Reality.] St. Petersburg: Iskusstvo-SPb. Available at https://www. booksite.ru/localtxt/pov/sed/nev/nost/index.htm, last accessed on 7 October 2020.

Boriak, Olena 2001. Z rukopisnikh fondiv IMFE: materiali do "zhinochikh studii' u pol'ovikh zapisakh Liudmili Shevchenko. [From the Manuscript Fonds of the Institute of Fine Arts, Folklore and Ethnology (IMFE) of the National Academy of Sciences of Ukraine: Materials on "Women's Studies" in Liudmila Shevchenko's Field Notes.] Arkhivi Ukraïni, Vol. 1-2, pp. 42-56.

Britsina, Oleksandra 2006. Ukraïns'ka usna traditsiina proza: pitannia tekstologiï ta vikonavstva. [Ukrainian Traditional Oral Prose: Questions on Textology and Performance.] Kyiv: Institut mistetstvoznavstva, fol'kloristiki, ta etnologii.

Budrowska, Bogusława 2000. Macierzyństwo jako punkt zwrotny $w \dot{z} y c i u$ kobiety. [Motherhood as a Turning Point in a Woman's Life.] Wrocław: Wydawnictwo Funna. Available at http://www.isns.uw.edu.pl/pliki/materialy_od_wykladowcow/ gender/Macierzynstwo-jako-punkt-zwrotny.pdf, last accessed on 7 October 2020.

Campbell, Joseph 2004 [1949]. The Hero with a Thousand Faces. Commemorative edition. Princeton \& Oxford: Princeton University Press. Available at http:// www.rosenfels.org/Joseph\%20Campbell\%20-\%20The\%20Hero\%20With\%20A\%20 Thousand\%20Faces,\%20Commemorative\%20Edition\%20\%282004\%29.pdf, last accessed on 7 October 2020.

Cherednikova, Maina 2002. "Golos detstva iz dal'nei dali..." (Igra, magiia, mif v detskoi kul'ture). [“The Voice of Childhood from a Far Distance...” (Play, Magic, and Myth in Children's Culture).] Moscow: Labirint. Available at https://www.booksite.ru/ fulltext/cherednikova/text.pdf, last accessed on 7 October 2020. 
Chubinskii, Pavel 1877. Trudy etnografo-statisticheskoi ekspeditsii v Zapadno-Russkii krai, snariazhennoi Imperatorskim Russkim geograficheskim obshchestvom. Iugo-zapadnyi otdel. [The Works of Ethnographic and Statistical Expedition into Western Russia Lands, Equipped by the Imperial Russian Geographical Society, South-Western Department.] Vol. 4: Obriady: rodiny, krestiny, svad'ba, pokhorony. St. Petersburg: Tipografiia V. Kirshbauma. Available at http://irbisnbuv.gov.ua/ulib/item/UKR0002510, last accessed on 7 October 2020.

Davis-Floyd, Robbie E. 1992. Birth as an American Rite of Passage. Berkeley \& Los Angeles \& London: University of California Press. Available at https://archive. org/details/isbn_9780520084315, last accessed on 7 October 2020.

Dianova, Tatiana 2009. Avtobiograficheskii diskurs i ustnaia fol'klornaia traditsiia: $\mathrm{k}$ metodologii issledovaniia. [Autobiographical Discourse and Oral Folklore Tradition: To the Methodology of Research.] Traditsionnaia kul'tura, No. 4, pp. 4-10. Available at http://www.trad-culture.ru/sites/default/files/files_pdf/ c4e614_e6a222e900cc4e57bb3af88448ed6b98.pdf, last accessed on 7 October 2020.

Eliade, Mircea 1959. The Sacred and the Profane: The Nature of Religion. New York: Harcourt, Inc.

Fine, Elizabeth Calvert 1984. The Folklore Text: From Performance to Print. Bloomington: Indiana University Press.

Florek, Stefan 2007. Genetyczne i środowiskowe determinanty miłości macierzyńskiej. [Genetic and Environmental Determinants of Maternal Love.] In: Bożena PłonkaSyroka (ed.) Miłośc kobiety: Społeczno-kulturowe mechanizmy kreowania emocji. Antropologia mitości, Vol. 1. Wrocław: Arboretum, pp. 27-49.

Gavriliuk, Natalia 1981. Kartografirovanie iavlenii dukhovnoi kul'tury (po materialam rodil'noi obriadnosti ukraintsev). [Mapping of the Phenomena of Spiritual Culture (Based on the Materials of the Maternity Rituals of Ukrainians).] Kyiv: Naukova dumka.

Geertz, Clifford 1973. The Interpretation of Cultures. New York: Basic Books, Inc. Available at https://monoskop.org/images/5/54/Geertz_Clifford_The_Interpretation_of_ Cultures_Selected_Essays.pdf, last accessed on 8 October 2020.

Grinchenko, Gelinada 2007. Usna istoriia: metodichni rekomendatsii $z$ organizatsiï doslidzhennia. [Oral History: Methodological Recommendations for Research Organization.] Kharkiv: Kharkivs'kii natsional'nii universitet imeni V.N. Karazina. Available at http://oralhistory.com.ua/assets/images/img_pubpraktikum/Metodyka_1_Grinchenko.PDF, last accessed on 8 October 2020.

Grushevskii, Marko 2006. Ditina u zvichaiakh i viruvanniakh ukraïns'kogo narodu. [Child in the Customs and Beliefs of the Ukrainian People.] Kyiv: Libid'. Available at http://chtyvo.org.ua/authors/Hrushevskyi_Marko/Dytyna_u_zvychayah_i_ viruvanniah_ukrainskoho_narodu/, last accessed on 8 October 2020.

Grushevskii, Marko (comp.) 1906. Ditina v zvichaiakh i viruvanniakh ukraïns'kogo narodu. Materiali z poludnevoi Kï̈vshchini. [Child in the Customs and Beliefs of the Ukrainian People. Materials from the Southern Kyiv Region.] Materiali do ukraïns'ko-rus'koï etnologiï, Vol. 8. Available at http://irbis-nbuv.gov.ua/ulib/ item/UKR0001197, last accessed on 8 October 2020.

Grushevskii, Marko (comp.) 1907. Ditina v zvichaiakh i viruvanniakh ukraïns'kogo narodu. Materiali z poludnevoï Kï̈vshchini. [Child in the Customs and Beliefs 
of the Ukrainian People. Materials from the Southern Kyiv Region.] Materiali do ukraïns'ko-rus'koï etnologiï, Vol. 9. Available at http://irbis-nbuv.gov.ua/ulib/ item/UKR0001202, last accessed on 8 October 2020.

Gura, Aleksandr 1997. Simvolika zhivotnykh v slavianskoi narodnoi kul'ture. [Symbolism of Animals in the Slavic Folk Culture.] Moscow: Indrik. Available at https:// inslav.ru/publication/gura-v-simvolika-zhivotnyh-v-slavyanskoy-narodnoytradicii-m-1997, last accessed on 8 October 2020.

Gura, Aleksandr 2009. Ryba. [Fish.] In: Nikita Tolstoi (ed.) Slavianskie drevnosti: etnolingvisticheskii slovar', Vol. 4. Moscow: Mezhdunarodnye otnosheniia, pp. 505-506.

Gvozdevich, Stephania 1997. Rodil'na obriadovist' ukrantsiv. [Maternity Rituals of the Ukrainians.] Narodoznavchi zoshiti, No. 2, pp. 111-122. Available at https:// archive.org/stream/zoshyty/\%D0\%9D\%D0\%B0\%D1\%80\%D0\%BE\%D0\%B4\%D 0\%BE\%D0\%B7\%D0\%BD\%D0\%B0\%D0\%B2\%D1\%87\%D1\%96\%20\%D0\%B7\%D 0\%BE\%D1\%88\%D0\%B8\%D1\%82\%D0\%B8\%201997\%202\#page/n49/mode/2up, last accessed on 8 October 2020.

Iashchurzhinskii, Hrisanf 1893. Pover'ia i obriadnosti rodin i krestin. [Birth and Christening Beliefs and Rituals.] Kievskaia starina, Vol. 42, pp. 74-83. Available at https://runivers.ru/bookreader/book479609/\#page/78/mode/1up, last accessed on 8 October 2020.

Ivanov, Petr 1992 [1991]. Narodnye rasskazy o dole. [Folk Stories about Fate.] In: Anatolii Ponomariov \& Tamara Kosmina \& Olena Boriak (eds.) Ukraïntsi: narodni viruvannia, povir’ia, demonologiia. 2nd ed. Kyiv: Libid', pp. 342-374. Available at http://irbis-nbuv.gov.ua/ulib/item/UKR0001994, last accessed on 8 October 2020.

Jung, Carl Gustav \& Kerényi, Carl 1971 [1949]. Essays on a Science of Mythology: The Myth of the Divine Child and the Mysteries of Eleusis. Revised edition. Princeton, N.J.: Princeton University Press.

Kabakova, Galina 1999. Deti nekreshchenye. [Unbaptized Children.] In: Nikita Tolstoi (ed.) Slavianskie dreunosti: etnolingvisticheskii slovar', Vol. 2. Moscow: Mezhdunarodnye otnosheniia, pp. 86-88. Available at https://vk.com/wall112143772_8486, last accessed on 8 October 2020.

Kabakova, Galina \& Sedakova, Irina 2004. Mladenets. [Infant.] In: Nikita Tolstoi (ed.) Slavianskie drevnosti: etnolingvisticheskii slovar', Vol. 3. Moscow: Mezhdunarodnye otnosheniia, pp. 257-264. Available at https://vk.com/wall-112143772_8486, last accessed on 8 October 2020.

Kachmar, Mariia 2010. Ukraïns'ka etiologichna legenda na storinkakh chasopisu "Zhite i slovo". [Ukrainian Etiological Legend on the Pages of "The Life and the Word" Periodical.] Ukraïns'ke literaturoznavstvo, No. 72, pp. 218-226. Available at http:// institutes.lnu.edu.ua/franko/wp-content/uploads/sites/7/ukr-literaturoznavstvo/ 72_2010/72_2010_m.kachmar.pdf, last accessed on 8 October 2020.

Kaindl, Raimund Fridrikh 2000. Gutsuli: ïkh zhittia, zvichaï ta narodni perekazi. [The Hutsuls: Their Life, Customs, and Folk Stories.] Chernivtsi: Molodii bukovinets'. Available at https://chtyvo.org.ua/authors/Kaindl_Raimund_Fridrikh/Hutsuly_ ikh_zhyttia_zvychai_ta_narodni_perekazy/, last accessed on 8 October 2020.

Kirshenblatt-Gimblett, Barbara 1989. Authoring Lives. Journal of Folklore Research, Vol. 26, No. 2, pp. 123-149. Available at http://www.jstor.org/stable/3814238, last accessed on 8 October 2020. 
Kravchenko, Vasil 1928. Zhittia rodinne v s. Bekhakh. Vesillia. Narodzhenets'. Vmirannia. [Family Life in the Village of Bekhi. Marriage. Childbirth. Dying.] Archive of the Institute of Art History, Folklore and Ethnology named after M. T. Ryl'skii of the National Academy of Sciences of Ukraine, fund 15, storage unit 158. Manuscript. Krugliakova, Tatiana 2001. Byt i fol'klor dorodovogo otdeleniia. [Life and Folklore of the Prenatal Service Department.] In: Sergei Nekliudov (ed.) Rodiny, deti, povitukhi $v$ traditsiiakh narodnoi kul'tury. Moscow: Rossiiskii gosudarstvennyi gumanitarnyi universitet, pp. 217-235. Available at https://www.booksite.ru/fulltext/ rodiny/text.pdf, last accessed on 8 October 2020.

Kulish, Panteleimon 1856. Zapiski o Iuzhnoi Rusi. [Notes about the Southern Rus'.] Vol. II. St. Petersburg: Tipografiia Aleksandra Iakobsona. Available at https:// cutt.ly/2rtVqOd, last accessed on 8 October 2020.

Malinka, Aleksandr 1898. Rodyny i khrestyny (material sobran v m. Mrin Nezhinskogo uezda). [Childbirth and Christening (Materials Collected in the Town of Mrin, Niezhyn County.] Kievskaia starina, Year 17, Vol. 61, pp. 254-286. Available at https://runivers.ru/bookreader/book479882/\#page/300/mode/1up, last accessed on 8 October 2020.

Malinowski, Bronislaw 1929. The Sexual Life of Savages in North-Western Melanesia: An Ethnographic Account of Courtship, Marriage, and Family Life among the Natives of the Trobriand Islands, British New Guinea. New York: Eugenics Pub. Co. Available at https://archive.org/details/sexuallifeofsava00mali/page/n3/mode/2up, last accessed on 8 October 2020.

Marander-Eklund, Lena 2000. Berättelser om barnafödande. Form, innehåll och betydelse $i$ kvinnors muntliga skildring av födsel. [Narratives of Childbirth: The Form, Content and Meaning in Women's Oral Depiction of Birth.] Diss. (PhD Thesis). Turku: Åbo Akademis förlag.

Marander-Eklund, Lena 2020. The Birth of a Child as Experienced and Narrated in 1990s Finland. Folklore: Electronic Journal of Folklore, Vol. 80, pp. 125-150. https://doi.org/10.7592/FEJF2020.80.marander_eklund.

Miller, Tina 2005. Making Sense of Motherhood: A Narrative Approach. Cambridge: Cambridge University Press. https://doi.org/10.1017/CBO9780511489501.

Mushinka, Mykola 1961. Narodzhennia ditini u zvichaiakh sela Kuriv Bardiïvs'kogo okrugu. [Childbirth Rites in the Village of Kuriv, Bardyiv District.] Duklia, No. 2, pp. 107-114.

Nowina-Sroczyńska, Ewa 1997. Przezroczyste ramiona ojca: Studium etnologiczne o magicznych dzieciach. [Father's Transparent Arms: Ethnological Study on Magical Children.] Łódź: Wydawnictwo Universytetu Łódźkiego.

Onishchuk, Antin 1912. Z narodn'ogo zhitia Gutsuliv. Rodini i khrestini, ta ditina do shostogo roku zhittia. [Childbirth, Cristening and Child until Six.] Materiiali do ukraïns'koï etnol'ogï, Vol. 15, pp. 90-113. Available at https://www.twirpx.com/ file/2155029/, last accessed on 8 October 2020.

Oring, Elliott 1987. Generating Lives: The Construction of an Autobiography. Journal of Folklore Research, Vol. 24, No. 3, pp. 241-262. Available at http://www.jstor. org/stable/3814333, last accessed on 8 October 2020.

Orszulak-Dudkowska, Katarzyna 2008. Ogtoszenie matrymonialne: Studium z pogranicza folklorystyki i antropologii kultury. [Matrimonial Advertisement: A Study from the 
Borderline of Folklore and Cultural Anthropology.] Łódzkie studia etnograficzne, Vol. XLVII. Łódz: Polskie towarzystwo ludoznawcze.

Orshuliak-Dudkovska, Katazhina 2010. Smaki mogo domu: Pamiat' - mif - naratsiia. [The Tastes of My Home: Memory - Myth - Narrative.] Studia methodologica, Vol. 30, pp. 49-54. Available at https://www.academia.edu/2450947/Studia methodologica_30, last accessed on 6 October 2020.

Panchenko, Aleksandr 2004. Otnoshenie k detiam v russkoi traditsionnoi kul'ture. [Attitude towards Children in Russian Traditional Culture.] Otechestvennye zapiski, No. 3, pp. 18-28. Available at https://magazines.gorky.media/oz/2004/3/ otnoshenie-k-detyam-v-russkoj-tradiczionnoj-kulture.html, last accessed on 8 October 2020.

Paukštytė-Šaknienè, Rasa 2020. Cycle of Birth Customs in Lithuania: Structural and Social Changes in Contemporary Society. Folklore: Electronic Journal of Folklore, Vol. 80, pp. 11-34. https://doi.org/10.7592/FEJF2020.80.paukstyte_sakniene.

Putilov, Boris 1999. Ekskursy v teoriiu $i$ istoriiu slavianskogo eposa. [Excursus into the Theory and History of the Slavic Epos.] St. Petersburg: Peterburgskoe vostokovedenie. Available at https://www.booksite.ru/fulltext/epos/text.pdf, last accessed on 9 October 2020.

Razumova, Irina 2000. Potaennoe znanie sovremennoi russkoi semi: Byt. Fol'klor. Istoriia. [Secret Knowledge of the Modern Russian Family: Everyday Life, Folklore, History.] Moscow: Indrik.

Rich, Adrienne 1976. Of Woman Born: Motherhood as Experience and Institution. New York \& London: W. W. Norton \& Co. Available at https://ru.scribd.com/ doc/242774285/Rich-Adrienne-Of-woman-born-Motherhood-as-experience-andinstitution-pdf, last accessed on 8 October 2020.

Sedakova, Irina 2007. Balkanskie motivy v iazyke i kul'ture bolgar. Rodinnyi tekst. [Balkan Motifs in Bulgarian Language and Culture: Birthlore.] Moscow: Indrik. Available at https://inslav.ru/publication/sedakova-i-balkanskie-motivy-v-yazykei-kulture-bolgar-rodinnyy-tekst-m-2007, last accessed on 8 October 2020.

Sedakova, Irina 2011. Kategoriia vremeni v slavianskom "tekste rozhdeniia": zachatie i beremennost'. [Category of Time in the Slavic "Text of Birth": Conception and Pregnancy.] In: Svetlana Tolstaia (ed.) Prostranstvo i vremia v iazyke i kul'ture. Moscow: Indrik, pp. 181-197. Available at https://inslav.ru/sites/default/files/ editions/2011_prostranstvo_i_vremja.pdf, last accessed on 8 October 2020.

Sedakova, Irina 2018. Bolgarskie predstavleniia o homo perfectus (Na materiale rodil'noi obriadnosti). [Bulgarian Views on Homo Perfectus (On the Data of Childbirth).] In: Svetlana Tolstaia (ed.) Obraz cheloveka v iazyke i kul'ture. Moscow: Indrik, pp. 144-160. DOI: 10.31168/2619-0834.2018.7.

Shchepanskaia, Tatiana 1999. Mifologiia sotsial'nykh institutov: rodovspomozhenie. [The Mythology of Social Institutions: Delivery Care.] In: Konstantin Bogdanov \& Aleksandr Panchenko (comps.) Mifologiia i povsednevnost': materialy nauchnoi konferentsii (Sankt-Peterburg, 24-26 fevralia 1999 goda). Vol. 3, pp. 389-423. Available at http://www.poehaly.narod.ru/repr-1.htm, last accessed on 8 October 2020.

Shcherbak, Inna 2008. Diti u narodnii terminologiï: leksika i simvolika. [Children in Folk Terminology: Vocabulary and Symbols.] In: Marina Grimich (ed.) Narodna 
kul'tura ukraïntsiv: zhittevii tsikl liudini: istoriko-etnografichne doslidzhennia. Vol. 1. Diti, ditinstvo. Ditiacha subkul'tura. Kyiv: Dulibi, pp. 50-59.

Shekerik-Donikiv, Petro 1918. Rodini i khrestini na Gutsul'shchini (v s. Golovakh i Krasnoïli Kosivs'kogo povitu). [Childbirth and Christening in Hutsul Region (in the Villages of Holovakh and Krasnoily, Kosiv District.] Materiali do ukrä̈ns'korus'koï etnologiï, Vol. XVIII, pp. 86-122.

Simonides, Dorota 1973. Współczesne podanie wierzeniowe. [Contemporary Belief Application.] Lud, Vol. 57, pp. 95-109.

Thurer, Shari L. 1994. Myths of Motherhood: How Culture Reinvents the Good Mother. New York: Penguin Books.

Titon, Jeff Todd 1980. The Life Story. The Journal of American Folklore, Vol. 93, No. 369, pp. 276-292. DOI: 10.2307/540572.

Tolstaia, Svetlana 1995. Beremennost', beremennaia zhenshchina. [Pregnancy, Pregnant Woman.] In: Nikita Tolstoi (ed.) Slavianskie drevnosti: etnolingvisticheskii slovar'. Vol. 1. Moscow: Mezhdunarodnye otnosheniia, pp. 160-164. Available at https:// vk.com/wall-112143772_8486, last accessed on 9 October 2020.

Vinogradova, Liudmila 1995. Otkuda deti berutsia? Polesskie formuly o proiskhozhdenii detei. [Where Do Children Come From? Formulas about the Origin of Children from the Region of Polesie.] In: Nikita Tolstoi (ed.) Slavianskii i balkanskii fol'klor: etnolingvisticheskoe izuchenie Poles'ia. Moscow: Indrik, pp. 173-187. Available at https://inslav.ru/images/stories/pdf/SBF-1995.pdf, last accessed on 9 October 2020.

Zielińska, Magdalena 2007. Postawy kobiet wobec macierzyństwa. [Women's Attitudes towards Motherhood.] In: Bożena Płonka-Syroka (ed.) Mitośc kobiety: Spotecznokulturowe mechanizmy kreowania emocji. Antropologia miłości. Vol. 1. Wrocław: Arboretum, pp. 49-67.

Oksana Labashchuk is Professor (PhD) at the Department of Theory and Methods of the Ukrainian and World Literature at Ternopil Volodymyr Hnatiuk National Pedagogical University, Ukraine. Her main research areas are anthropology and narratology studies, folk beliefs and narratives, folklore.

lov081168@tnpu.edu.ua

Halyna Derkach is Assistant Professor ( $\mathrm{PhD}$ ) at the Department of Foreign Languages at Ternopil Volodymyr Hnatiuk National Pedagogical University, Ukraine. Her latest research deals with comparative studies, anthropology and narratology studies, folklore.

halder@tnpu.edu.ua

Tetiana Reshetukha is Assistant Professor (PhD) at the Department of Journalism at Ternopil Volodymyr Hnatiuk National Pedagogical University, Ukraine. Her latest research deals with social communications, anthropology and narratology studies, folklore.

reshtetyana@tnpu.edu.ua 